\title{
CHANGE-SEEKING BEHAVIOR AND SELF-IDENTITY IN THE SATISFACTION OF BRAZILIAN BACKPACKERS WITH INTERNATIONAL BACKPACKING TRIPS
}

\author{
D Carlos Yuri Ramos de Araujo \\ Mestre em Hotelaria e Turismo \\ Universidade Federal de Pernambuco/Programa de Pós-Graduação em Hotelaria e Turismo \\ yuriiaraujo@gmail.com \\ iD Marconi Freitas da Costa \\ Doutor em Administração \\ Universidade Federal de Pernambuco/Programa de Pós-Graduação em Gestão, Inovação e \\ Consumo \\ marconi.fcosta@ufpe.br \\ Talita Poliana Guedes da Silva \\ Mestre em Hotelaria e Turismo \\ Universidade Federal de Pernambuco/Programa de Pós-Graduação em Hotelaria e Turismo \\ talita.gsilva@ufpe.br
}

\begin{abstract}
Goal of the study: This study investigated how change-seeking behaviour, global and local selfidentities influence Brazilian backpackers' satisfaction with their international backpacking trips.

Methodology / approach: We conducted a questionnaire survey with Brazilian backpackers ( $\mathrm{n}=213)$. Data collected were submitted to an exploratory factor analysis (EFA) and multiple linear regression (MLR) technique in SPSS.

Originality / Relevance: The present study is original because it proposes unprecedented notions of identity as a factor of influence in the satisfaction of the backpacker, so far an under researched topic.

Main results: Results indicate that change-seeking behaviour and global self-identity in Brazilian backpackers influence their satisfaction with the trip. Other findings showed how the subjects have higher proficiency in foreign languages and certain geographical preferences.

Theoretical / methodological contributions: The main contribution of this research is that changeseeking behavior and global self-identity are positively associated with the satisfaction of Brazilian backpackers with their international trips. Thus this work shows that consumer's satisfaction is influenced by identity matters.
\end{abstract}

Keywords: Change seeking. Self-identify. Tourist satisfaction. Backpacker. International trips.

\section{Cite como}

American Psychological Association (APA)

Araujo, C. Y. R., Costa, M. F., \& Silva, T. P. G. (2021, set./dez.). Change-seeking behavior and selfidentity in the satisfaction of brazilian backpackers with international backpacking trips. PODIUM Sport, Leisure and Tourism Review, São Paulo, 10(4), 109-135. https://doi.org/10.5585/podium.v10i4.19020. 
Araujo, C. Y. R., Costa, M. F., \& Silva, T. P. G. (2021, set./dez.). Change-seeking behavior and selfidentity in the satisfaction of brazilian backpackers with international backpacking trips

\section{COMPORTAMENTO DE BUSCA DE MUDANÇA E AUTOIDENTIDADE NA SATISFAÇÃO DE MOCHILEIROS BRASILEIROS COM VIAGENS INTERNACIONAIS DE MOCHILEIROS}

\section{Resumo}

Objetivo do estudo: Este estudo investigou como o comportamento de busca por mudanças e as autoidentidades globais e locais influenciam a satisfação dos mochileiros brasileiros com suas viagens internacionais.

Metodologia / abordagem: Realizamos uma pesquisa por questionário com mochileiros brasileiros (n =213). Os dados coletados foram submetidos à técnica de análise fatorial exploratória (AFE) e regressão linear múltipla (RLM) no SPSS.

Originalidade / Relevância: O presente estudo é original porque propõe noções inéditas de identidade como fator de influência na satisfação do mochileiro, até então um tema pouco pesquisado.

Principais resultados: Os resultados indicam que o comportamento de busca por mudanças e a autoidentidade global em mochileiros brasileiros influenciam sua satisfação com a viagem. Outras descobertas mostraram como os sujeitos têm maior proficiência em línguas estrangeiras e certas preferências geográficas.

Contribuições teórico-metodológicas: A principal contribuição desta pesquisa é que o comportamento de busca por mudanças e a autoidentidade global estão positivamente associadas à satisfação dos mochileiros brasileiros com suas viagens internacionais. Assim, este trabalho mostra que a satisfação do consumidor é influenciada por questões de identidade.

Palavras-chave: Busca de mudança. Autoidentificação. Satisfação do turista. Backpacker. Viagens internacionais.

\section{COMPORTAMIENTO DE LA BÚSQUEDA DEL CAMBIO Y LA PROPIA IDENTIDAD EN LA SATISFACCIÓN DE LOS MOCHILEROS BRASILEÑOS CON VIAJES INTERNACIONALES PARA MOCHILEROS}

\section{Resumen}

Objetivo del estudio: Este estudio investigó cómo el comportamiento de búsqueda del cambio y las autoidentidades globales y locales influyen en la satisfacción de los mochileros brasileños con sus viajes internacionales.

Metodología / enfoque: Realizamos una encuesta por cuestionario con mochileros brasileños $(n=213)$. Los datos recolectados fueron sometidos a la técnica de análisis factorial exploratorio (AFE) y regresión lineal múltiple (RLM) en SPSS.

Originalidad / Relevancia: El presente estudio es original porque propone nociones inéditas de identidad como factor de influencia en la satisfacción del mochilero, que hasta ese momento era un tema poco investigado.

Resultados principales: Los resultados indican que el comportamiento de búsqueda del cambio y la autoidentidad global de los mochileros brasileños influye en su satisfacción con el viaje. Otros hallazgos han demostrado cómo los sujetos son más competentes en idiomas extranjeros y ciertas preferencias geográficas.

Aportes teórico-metodológicos: El principal aporte de esta investigación es que el comportamiento de búsqueda del cambio y la autoidentidad global se asocian positivamente con la satisfacción de los mochileros brasileños con sus viajes internacionales. Así, este trabajo muestra que la satisfacción del consumidor está influenciada por cuestiones de identidad.

Palabras clave: Búsqueda de câmbios. Autoidentificación. Satisfacción del turista. Mochilero. Viajes internacionales. 
Araujo, C. Y. R., Costa, M. F., \& Silva, T. P. G. (2021, set./dez.). Change-seeking behavior and selfidentity in the satisfaction of brazilian backpackers with international backpacking trips

\section{Introduction}

Beyond its economic characteristic, tourism can also be seen as a radiator of new sociocultural human expressions (Lohmann \& Panosso Neto, 2012; Wang et al., 2020). Such expressions are subjective and are part of the lifestyles of travelers (Cohen, 2011). Through these subjective expressions, travelers can achieve cathartic or transformative experiences of being (Zahra \& Mcintosh, 2007). Backpacking is a type of travel that presents profound personal changes and feelings of eudaimonia, that is, being the best possible version of yourself (Noy, 2004). According to Collins-Kreiner, Yonay and Even (2018), backpackers remember their travels as strongly significant experiences and with profound effects of self-reflection.

The term backpacker refers to a group of predominantly young travelers who tend to stay in low-cost accommodations, have an emphasis on meeting other travelers, are independent and have a flexible itinerary (Dayour, Park \& Kimbu, 2019). In addition, backpackers prefer long periods of travel, focusing on informal and participatory activities (Pearce, 1990). Given the characteristics of independence, youth and flexibility, in addition to the search for participatory activities, it is justifiable to say that identity matters and change-seeking behavior might affect the satisfaction that backpackers have with their trip.

Globalization phenomena such as tourism have an influence and are influenced by matters of identity (Arnett, 2002). According to Arnett, one of the consequences of globalization is that most people in the world today develop a bicultural identity, where part of their identity is rooted in local culture while another part is generated by the awareness of their relationship with global culture. In this work, it is understood that the backpacker, due to their characteristics, presents themselves as a suitable study subject to understand more about identities and their relationship with tourism.

Global self-identity can be understood as the identification of a person with people around the world and also the desire to know what is happening to him. Identity is a theme that runs through the backpacker segment and is an integral part of the very identity of certain travelers (Cohen, 2011). Thus, it is proposed that the global self-identity positively influences the satisfaction with the backpacker's trip. In turn, local self-identity may have the opposite influence on backpacking activity.

Backpacking is a practice that provides an encounter with oneself and an experience of discovering the self identity of those who practice it, thus developing a sense of belonging to the place or to something that is similar to their ideals and preferences (Alves et. Al, 2016). 
Araujo, C. Y. R., Costa, M. F., \& Silva, T. P. G. (2021, set./dez.). Change-seeking behavior and selfidentity in the satisfaction of brazilian backpackers with international backpacking trips

From this, it is necessary to understand the concept of local self-identity that is part of the complex of self-identity and concerns the degree to which a person identifies with the people, traditions and events in their local community. In other words, while global self-identity is about people around the world, local self-identity is related to the appreciation of traditional local culture and the feeling of belonging to the community of origin. With the focus of this study on Brazilian backpackers, it is believed that a strong degree of local self-identity can negatively influence satisfaction with an international backpacking trip.

Change-seeking behavior is another apparent feature of backpackers. The changeseeking behavior would be the characteristic of a person to express the desire for variation or stimulus of differentiation in their life (Steenkamp, Jan-Benedict \& Baumgartner, 1995). Noy (2004) suggests that backpackers give importance to backpacking's transformative capacity and how it can provide rich opportunities for new experiences. Change-seeking behavior also seems to interact with consumer identity matters. This construct may be related to the satisfaction of a backpacker with their trip as backpacking presents opportunity for variety and change.

The backpacker is part of a growing segment (Chen, Zhao \& Huang, 2020). However, due to their characteristics of independence, informality and search for low costs (Pearce, 1990) this type of tourist can escape the influence of part of the tourist trade. Understanding this segment is essential to develop solutions that allow companies large and small to focus on this emerging segment effectively. Understanding whether the satisfaction of the Brazilian backpacker is linked to a high degree of global self-identity may indicate the need to reinforce the appeal for globalization in marketing aimed at backpackers, for example. In addition, it is essential to understand the development of a latent globalized identity formation.

The present study is original because it proposes unprecedented notions of identity as a factor of influence in the satisfaction of the backpacker, so far an under researched topic. The literature related to backpackers had not yet identified the relationship between these characteristics of the identity of this type of traveler and their satisfaction with the backpacking. The backpacker's identity is something studied by tourism researchers in several aspects, and as highlighted by many scholars, backpacking is one of the ways that individuals seek to carry out their self-change (Noy, 2004), to rebuild their personal identities (Cohen, 2010) and achieve their personal development (Chen, Bao \& Huang, 2014; Alves et. al, 2016). Zhang et. al (2017) affirm that it is necessary to increase the range of knowledge regarding the construction of backpackers' identity, although some exploratory studies have already highlighted important characteristics. 
Araujo, C. Y. R., Costa, M. F., \& Silva, T. P. G. (2021, set./dez.). Change-seeking behavior and selfidentity in the satisfaction of brazilian backpackers with international backpacking trips

Therefore, the following research question is posed: how does the change-seeking behavior and global and local self-identities influence Brazilians satisfaction with international backpacking trip

\section{Literature review}

Backpacking and backpackers

In a literature review conducted by Chen and Huang (2019) it was found that research on the topic of backpackers has evolved over the past 75 years. With the advance of globalization, this phenomenon becomes an important movement of people who move internationally in search of knowing and experiencing new places and cultures.

In an introductory way, backpacking is an alternative type of travel, traditionally opposed to institutionalized mass tourism (Cai, Cohen \& Tribe, 2019). Although authors claim to observe a change in the profile of the international backpacker with tendencies towards massification (Edensor, 2001; Falconer, 2013), they themselves conceive the current definitions as still relevant. In a recent research note, the Annals of Tourism Research journal reports that researchers use different criteria to conceptualize the 'backpacker' and the type of travel they do without developing an operational criterion commonly accepted by all as complete (Dayour, Kimbu \& Park, 2017).

The lack of a common and precise definition can really call into question the operability and generability of the data collected: are the studies really working with the same research subject? In order to establish defined backpack / backpacker definition criteria to operationalize this research, this topic will present the most common and referenced definitions, the backpack and backpacker characteristics reported in relevant research and, finally, it will bring its own definitions to be used in this research.

The backpacker is characterized in the literature mostly as a young and independent traveler looking for adaptable itineraries on longer trips (Chen, Zhao \& Huang, 2020). One of the backpacker's most striking characteristics as a consumer is their search for low cost accommodation and a focus on informal and participatory activities. Other criteria used in scientific research to delimit the backpacker are sociodemographic aspects, such as age (Loker, 1991), or consumption patterns, such as accommodation in hostels rather than hotels (Pearce, 1990), carrying backpacks (Zhang et al, 2017), traveling for months or years (O'Reilly, 2006), 
Araujo, C. Y. R., Costa, M. F., \& Silva, T. P. G. (2021, set./dez.). Change-seeking behavior and selfidentity in the satisfaction of brazilian backpackers with international backpacking trips

participating in virtual communities for backpackers (Paris, 2012) and even identifying themselves as backpackers (Cohen, 2011; Uriely, Yonay \& Simchai, 2002).

Brazilian author Nakamura (2015) defines the backpacker as a predominantly young person, with little financial resources who wants to visit a large number of places in the same travel itinerary. Her definition does not mention the length of travel, but rather the number of destinations visited in a single trip. This may point to a possible difference between the Brazilian backpacker and the backpacker in the Northern Hemisphere: instead of looking for very long trips, Brazilian backpackers tend to prefer visiting the largest possible number of different countries in a single trip. It is possible that this difference is caused by economic and identity factors.

Here the backpacker is understood as an independent traveler, with a limited and predetermined budget that seeks to reduce costs in lodging, transportation and / or food in order to save for more experiences (Dayour, Park \& Kimbu, 2019); who travels longer than the average mass tourist carrying less luggage, who identifies as a backpacker or participates in online experience sharing groups. The traveler who fits all or most of these characteristics will be defined as a backpacker in this research. However, it is important to emphasize that due to methodological characteristics, self-identification as a backpacker will be implicitly framed in the given definition. The type of travel this tourist takes as a backpacker is backpacking.

In view of the purpose of this article to investigate the influence of self-identity and change-seeking behavior in the satisfaction of Brazilians with international backpacking trip, the next topics will address the most relevant constructs and research on the topic.

\section{Global and local self-identities}

With the advent of globalization and a steady growth of global market, consumers can now choose from a variety of local as well as global brands and products. However, research shows that the global-local relationship goes beyond consumer product choice; it seems to indicate an influence on consumers' own identity, which in return will influence their choices. American psychologist Arnett (2002) first developed a local-global identity construct where young people develop a global identity due to facing a much-globalized world while at the same time maintaining their traditional local identity. Because globalization has also provoked nationalistic trends and a return to "the local" (Hermans \& Dimaggio, 2007), developing this 
Araujo, C. Y. R., Costa, M. F., \& Silva, T. P. G. (2021, set./dez.). Change-seeking behavior and selfidentity in the satisfaction of brazilian backpackers with international backpacking trips

dual identity helps people embrace global community and create a sense of belonging to the world without losing touch with their origins and culture.

Global self-identity is one's identification with other people around the world, interest in global events and the recognition of commonalities rather than dissimilarities among peoples of the world (Tu, Khare \& Zhang, 2012, p.36). High global self-identification has been linked to preference to global products (Batra et al, 2000), stronger social networking sites usage (Makri et al., 2019), pro-environmental attitudes (Rosenmann, Reese \& Cameron, 2016) and intentions to act collectively against climate change (Barth et al., 2015).

Technology, internet and TV are crucial for the development of global identity (Arnett, 2002), and so is tourism. Cohen (2011) suggests that backpacking travelers, in particular, adopt a hybrid and post-modern identity and that globalization is leading to new ways of relating to places and understanding identities. Backpackers are exploring the world to look for authentic local experiences in places sometimes very alien to their local cultures, not without risks. Wantono and McKercher (2019) investigated risk perception in Asian backpacker women traveling solo and found that despite the cultural, racial and gender risks, Asian women backpackers are traveling more.

In Brazil, the process of globalization was sped up after the presidency of Fernando Henrique Cardoso. In this period, Brazil fully joined neoliberalism and opened its markets to foreign competition and big corporations (Burity, 2008). The role of globalization in Brazil has had real and rhetoric effects and marked "the new face of Brazilian society" since the 1990s (Burity, 2008). International TV channels coupled together with high internet usage suggest a transnational digital culture and socialization with most of the Western world (Barbosa et al, 2013). We propose the following hypothesis based on the discussion above:

H1: Global self-identity positively influences Brazilians satisfaction with international backpacking trip.

The local and the global are axial principles of contemporary times (Tomlinson, 1999). Burity (2008) argues that it is crucial to focus on the global/local dynamic to fully capture a cultural dimension. It is because along their global self-identity, people keep developing local self-identity (LSI).

LSI is based on local circumstances, environment and traditions of the place where these people grew up. According to Arnett (2002), this identity is the one that people use most often in their daily interactions with family, friends and community members. Part of the more general concept of local identity is national identity. The latter is defined as a general feeling 
Araujo, C. Y. R., Costa, M. F., \& Silva, T. P. G. (2021, set./dez.). Change-seeking behavior and selfidentity in the satisfaction of brazilian backpackers with international backpacking trips

of emotional bond or belonging to a nation (Blank and Schmidt, 2003). Local identity is thus understood as a broader concept encompassing the notion of the larger nation and also the most intimate and specific place one might say they belong to.

This self-identity seems to lead to a locally-oriented consumption practice. Evidence shows that a strong local identity led to a preference for local products over global products (Shimp \& Sharma, 1987). Many consumers prefer local consumption imagery because they more easily identify with local lifestyles, values, attitudes, and behaviors (Crane, 2002). They may more easily identify with local tradition due to using it more frequently in their daily lives with friends and family, as Arnett puts it.

Strizhakova and Coulter review (2019) suggests four categories of global-local identities: strong global and local identity, stronger global (weaker local) identity, stronger local (weaker global) identity and unengaged. This seems to point to the possibility of inverse relationship between strong global identity and strong local identity.

Backpackers develop their own sense of belonging in the search for similarities, personal identifications or something they want to share with, creating communities (Paris, 2010; Alves et al, 2016). In contrast, in the reality of Chinese backpackers, Zhang et al. (2018) claim that self-alienation did not have a significant influence on the construction of the identity of these backpackers, because although there is a relationship between these travelers and their local reality, there is a predominance of the search for the sense of life through backpacking. International backpacking travel being a very globalized product, we propose in this article that a strong local identity will have a negative influence on Brazilians satisfaction with their international backpacking trip:

H2: Local self-identity negatively influences the satisfaction of Brazilians with international backpacking trip.

The quest to comprehend backpackers' identity does not stop there, however. Another important piece in this puzzle may be the change-seeking behaviour of backpackers. In the next topic, we will discuss this particular behaviour.

\section{Change-seeking behavior}

It has already been pointed out that backpackers go through profound changes resulting from their travels (Noy, 2004). These changes are notably perceived as positive by backpackers and are rhetorically connected to the question of self-identity. Garlington and Shimota (1964) 
Araujo, C. Y. R., Costa, M. F., \& Silva, T. P. G. (2021, set./dez.). Change-seeking behavior and selfidentity in the satisfaction of brazilian backpackers with international backpacking trips

reported that changing stimuli is an important part of human behavior and that this search for different stimuli varies from person to person. For the authors, the change-Seeking would be a habitual and consistent pattern of behavior that acts to control the amount and type of stimulus received by a particular organism. The sources for stimuli can be internal, like cognition itself, or external.

Steenkamp and Baumgartner (1995) realized that the optimal level of stimulation of the human being is linked to the desire to explore. This construct is also associated with curiosity and the search for novelties and sensations (Bello \& Etzel, 1985). Later, Lee and Crompton (1992) links novelty-seeking behavior to the pursuit of emotion, change of routine, relief from boredom and surprise. In other words, subjects showing change-seeking behavior are looking for something new that provokes interest to be explored. Thus, the behavior of seeking change can present itself as a possible factor in a traveler's satisfaction with the backpacking trip.

Backpackers seek changes not only in activities, but also in personality and identity. According to Noy (2004), even backpackers whose trips are more recreational and less contemplative give importance to the transformative and multivariate capacity of backpacking. Regarding motivation, Chinese backpackers can be described as individuals who are more willing to explore the unknown world and seek experiences of risk and authenticity, promoting a search for changes in their lives (Zhang, Morrison, Tucker \& Wu, 2018). Chen, Huang and $\mathrm{Hu}$ (2019) claim that these changes at different stages can affect backpackers' self-esteem and consequently their backpacking experience and satisfaction levels. In this sense, the research by Chen and Huang (2017) suggests that western backpackers see the backpack as a more "individualistic" form of personal development.

Cohen (2003), on the other hand, draws attention to the discrepancy between theory and reality in the particular case of the backpacker traveler. The author states that backpackeroriented travel agencies create the impression that backpacking offers real adventures in unexplored areas, which may not be manifested in reality. The strategy exemplified by Cohen is more of a marketing attempt to appeal to the search for change and novelty that is presented by backpackers. These marketing campaigns may backfire if it does not fulfill backpacker's expectations, leading to reduced customer satisfaction.

Martensen (2018) states that the variety-seeking behavior is related to consumer loyalty. Kytöa, Virtanenb and Mustonenc (2019) found out that consumers with higher intention of buying a certain product (intenders) also presented stronger change-seeking behavior, which may indicate that change-seekers are more likely to try new products. In this study it is proposed 
Araujo, C. Y. R., Costa, M. F., \& Silva, T. P. G. (2021, set./dez.). Change-seeking behavior and selfidentity in the satisfaction of brazilian backpackers with international backpacking trips

that the behavior of change-seeking behavior is related to the satisfaction of the Brazilian backpacker with their international trip, influencing it positively. The following hypothesis is proposed:

H3: Change-seeking behavior positively influences the satisfaction of Brazilians with international backpacking trip.

Figure 1 shows the theoretical model proposed for the research. We proposed that global self-identity (GSI) positively influences backpacking satisfaction (SIB), while local selfidentity (LSI) negatively influences the same variable (SIB). Change-seeking behavior (CSB) positively influences satisfaction with international backpacking trip (SIB).

Figure 1.

Proposed Conceptual Model.

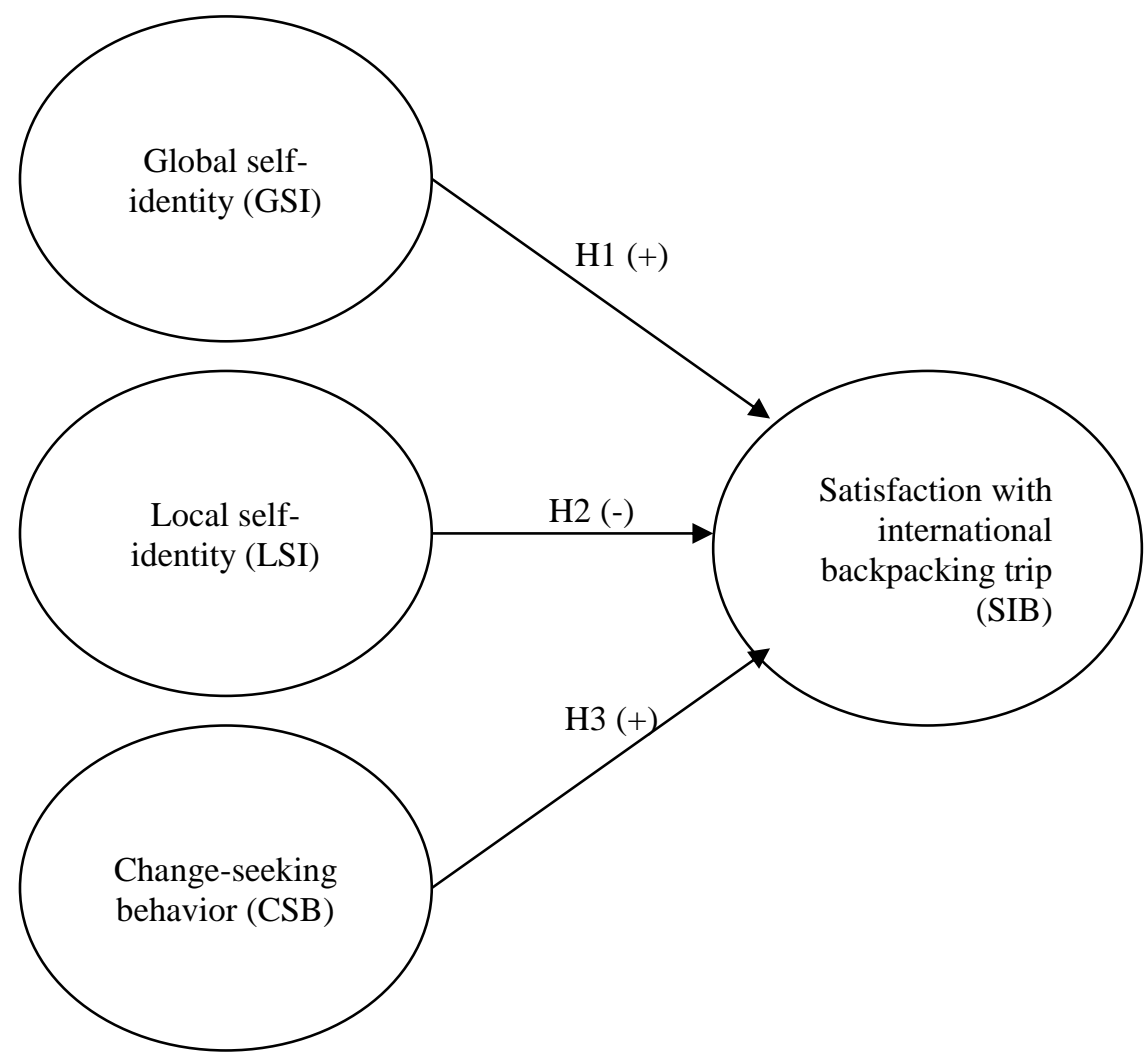

Source: Prepared by the authors. 
Araujo, C. Y. R., Costa, M. F., \& Silva, T. P. G. (2021, set./dez.). Change-seeking behavior and selfidentity in the satisfaction of brazilian backpackers with international backpacking trips

\section{Materials and methods}

The guiding paradigm of this research is post-positivism, thinking after positivism, which "recognizes that we cannot be 'positive' about our statements of knowledge when we study the behavior and actions of human beings" (Creswell, 2010, p. 29). A single crosssectional descriptive research concept was adopted (Malhotra, 2012; Costa et al., 2017). In an exploratory way, bibliographic research was conducted on the ScienceDirect, Scopus, Google Scholar, Scielo, Capes Periodicals and Tourism Publications portals. As a research strategy, an online survey was applied to investigate the influences of global self-identity, local self-identity and change-seeking behavior on the variable satisfaction with international backpacking trip (SIB). It is noteworthy that the research complied with research ethical standards and conduct (Batista et al., 2013), although approval by an ethics committee was not required due to the profile of the study.

\section{Population and sample}

The population of this study was any and all Brazilian individuals that have traveled or were traveling at the time as a backpacker outside Brazil. Sampling is non-probabilistic by convenience (Malhotra, 2012). That said, it is reinforced that the results of this research are not generalizable to the entire population.

The sample selection criteria taken by this research were: 1) having access to the internet at the time of the interview; 2) be a member in the social networks listed below or similar ones: Mochileiros na Europa (Backpackers in Europe), Mochileiros na America Latina (Backpackers in Latin America) and Mochileiros na Ásia (Backpackers in Asia). Those are all prominent Whatsapp groups for Brazilian backpackers. Two other major Facebook communities were contacted, Economic Travel - Backpackers and Travelers and Backpackers around the World. Brazilian Instagram users who have used hashtags such as \#mochilao, \#mochileiro, \#mochilando. The snowball technique also provided access to a larger sample of respondents. The minimum number of respondents required for sampling was 165 , considering the rule of at least 5 respondents per question in the questionnaire. 
Araujo, C. Y. R., Costa, M. F., \& Silva, T. P. G. (2021, set./dez.). Change-seeking behavior and selfidentity in the satisfaction of brazilian backpackers with international backpacking trips

\section{Data collection procedures}

To meet the needs of the online survey, the data collection instrument used was the structured questionnaire, developed through Google Forms. The instrument was build standardized through scales selected from the theoretical framework.

To measure the construct of global self-identity (GSI) we applied the Westjohn et al. (2009) scale that measures the degree of connection between the individual and the world and the desire to be connected to global events. The scale for the Local self-identity (LSI) construct came from the studies by Zhang and Khare (2009) and Zhang and Khare (2008). The local selfidentity scale (LSI) measures the degree to which a person identifies with the people, traditions and events in their local community. Change-seeking behavior (CSB) as found in Steenkampand Baumgartner (1995) is a seven-item scale derived from the Change-Seeking Index. To measure the dependent variable, satisfaction with international backpacking trip (SIB), a two-item general satisfaction scale used by Wallace, Giese and Johnson (2004) was adapted and applied. The adaptation consisted of the addition of the item SIB03 (would you take another international backpacking trip?).

Every construct of the theoretical model was measured using seven-point likert scales, with descriptors being 1 - totally disagree to 7 - totally agree, exception being SIB scale whose descriptors ranged from 'very dissatisfied' to 'very satisfied' and "Terrible / happy". The table below (table 1) shows the composition of the questionnaire with the name of the construct and acronym, source and items, in addition to the codes applied to the constructs. The scales originally in English were translated into Brazilian Portuguese by the authors, and then validated by reverse translation and further proofreading by a native English speaker with a good command of Portuguese.

Table 1.

Scales

\begin{tabular}{|c|c|c|}
\hline Construct & Scale items & Code \\
\hline Global
\end{tabular}

Global self- I feel like I'm living in a global village. $\quad$ GSI01 identity (GSI)

I feel that what I do can affect someone around the world.

GSI02 
Araujo, C. Y. R., Costa, M. F., \& Silva, T. P. G. (2021, set./dez.). Change-seeking behavior and selfidentity in the satisfaction of brazilian backpackers with international backpacking trips

Westjohn et al I feel that I am a "neighbor" to people who live in other parts of the GSI03 (2009) world.

I feel that I am connected to everyone in the world as if they were my GSI04 family.

I feel that people around the world are more alike than different.

GSI05

Local self-identity I am aware of local events.

LSI01

(LSI)

Zhang \& Khare

I believe that I belong mainly to my local community.

LSI02

(2009); Zhang \&

Khare (2008)

I like to meet people from my local community.

LSI03

I believe that local communities are different from each other.

LSI04

I believe that the local way of life is hampered by globalization.

I respect my local traditions.

I believe that parents should pass on local customs to their children.

I like to know more local news than world news.

I believe that the local consequences of our actions are more important than those global consequences.

I can more easily find people who think the same way as I do in my

LSI10 community than outside.

Change-seeking behavior (CSB)

I like to keep doing the same old things, instead of trying new and different things $(r)$

Steenkamp

Baumgartner (1995)

I like a job that offers changes, variety and travel, even if it involves some danger.

I am continually looking for new ideas and experiences.

I like to continually change activities.

When things get boring, I like to find some new and unknown CSB06 experience.

I prefer a routine way of life to an unpredictable one, full of changes (r). CSB07

Satisfaction with international backpacking trip (SIB)
All things considered, how satisfied were you with your backpacking SIB01 trip?

All things considered, how do you feel about your backpacking trip? 
Araujo, C. Y. R., Costa, M. F., \& Silva, T. P. G. (2021, set./dez.). Change-seeking behavior and selfidentity in the satisfaction of brazilian backpackers with international backpacking trips

Wallace, Giese \&

Would you take another backpacking trip?

SIB03

Johnson (2004).

Adapted by the

authors (2019).

Source: Prepared by the authors.

A pre-test was carried out with 15 individuals in order to point out weaknesses in the instrument. After the pre-test, there was the refinement stage (Babbie, 2003). Data collection was carried out for two weeks in October 2019. Access to the questionnaire was made available through a link in posts on the WhatsApp, Facebook and Instagram platforms. 214 respondents were obtained, totaling 213 after cleaning the data and excluding one respondent.

\section{Data analysis procedures}

Aiming at a greater detail of the data, the analysis was divided into two phases. A descriptive analysis (percentage, mean and standard deviation) was the strategy used to investigate the sociodemographic profile of the sample collected $(n=213)$.

In the next phase, we sought to determine the reliability of the constructs. Cronbach's alpha technique was used, accepting indices equal to or greater than 0.6. The Kaiser-MeyerOlkin (KMO) and Bartlett's sphericity tests were used to verify the dimensionality of the items, consisting of an exploratory factor analysis. In the analysis of the proposed theoretical model, multiple linear regression analysis was used. The purpose of the analysis was to confirm or reject the three proposed hypotheses.

\section{Results and discussion}

At the end of the collection period, the questionnaire on the Google Forms platform was closed and the data generated was saved in .xlsx digital format. The data was cleaned up. After removing a component from the total sample, the final sample was composed of 213 respondents. Then the database was imported into SPSS in order to carry out the proposed analyzes. 
Araujo, C. Y. R., Costa, M. F., \& Silva, T. P. G. (2021, set./dez.). Change-seeking behavior and selfidentity in the satisfaction of brazilian backpackers with international backpacking trips

\section{Sociodemographic profile of respondents}

The respondents' sociodemographic profile was estimated by simple descriptive statistics. The profile concerns gender, age, family income, educational level, region of origin, marital status, foreign language skills and continents visited during backpacking trip.

\section{Table 2.}

Sociodemographic Profile: Age and Income

\begin{tabular}{l|c|c|c|}
\hline Variables & Mean & S.D.* & C.V.** \\
\hline Age & 29,99 & 6,479 & $21,6 \%$ \\
Average monthly income (family) & $\mathrm{R} \$ 6.687,59$ & 5132,669 & $76 \%$ \\
\hline Source: Field research database. Note. *S.D.=standard deviation. **Coefficient of \\
variation.
\end{tabular}

Two variables of the sociodemographic profile were measured on ratio scales: average monthly family income and age. Table 2 shows the mean, standard deviation and coefficient of variation. On average, the participating backpackers are 30 years old and have an average monthly family income of $\mathrm{R} \$ 6,687.59$. The national average for the 2017-2018 period in Brazil was $\mathrm{R} \$ 5,426.70$ (IBGE, 2019). The sample of this study states $23 \%$ higher income than the national average, showing a social strata of greater purchasing power. Table 3 shows a gender-balanced sample. At the educational level, 74.7\% of respondents have already completed higher education and $24 \%$ are at master's or doctorate level. The region with the most respondents was the Southeast, with 53.5\%. The other three regions of the country together make up only $30 \%$ of the total sample. Singles are $80.3 \%$ of the sample.

\section{Table 3.}

Sociodemographic Profile: Gender, Educational Level, Origin and Marital Status

\begin{tabular}{|l|r|l|c|}
\hline Gender & $\%$ & Region of origin & $\%$ \\
\hline Female & $51,2 \%$ & Southeast & $53,5 \%$ \\
Male & $46,9 \%$ & Northeast & $22,5 \%$ \\
Non-binary & $1,9 \%$ & South & $16,4 \%$ \\
\cline { 1 - 1 } Educational level & $\%$ & Midwest & $6,6 \%$ \\
\cline { 1 - 1 } High school & $2,3 \%$ & North & $0,9 \%$ \\
\cline { 5 - 5 } Ongoing graduation & $23,0 \%$ & Marital Status & $\%$ \\
Graduated & $50,7 \%$ & Single & $80,3 \%$ \\
Master's & $20,7 \%$ & Married & $15,0 \%$ \\
Doctorate & $3,3 \%$ & Divorced / Widower & $4,7 \%$ \\
\hline
\end{tabular}

Source: Field research database. 
Araujo, C. Y. R., Costa, M. F., \& Silva, T. P. G. (2021, set./dez.). Change-seeking behavior and selfidentity in the satisfaction of brazilian backpackers with international backpacking trips

Table 4 summarizes the linguistic level of participants in English, Spanish and fluency in any other language apart from the aforementioned two. In addition to these, the table shows the continents most visited by the Brazilian backpackers interviewed. English is spoken at some level by $94.4 \%$ of participating Brazilian backpackers, with $54 \%$ self-reported as advanced speakers of the language. On the other hand, 28.6\% did not speak Spanish at any level, with $53.38 \%$ of backpackers between basic or intermediate Spanish. Languages not Engish or Spanish are spoken by $22.5 \%$ of backpackers. Backpacking trips are mostly to Europe (67.6\%), with South America right afterwards in the choice of participating Brazilian backpackers $(48.8 \%)$.

Table 4.

Sociodemographic Profile: Language Skills (SelfReported) and Continents Visited

\begin{tabular}{|c|c|c|c|}
\hline English & $\%$ & Visited continentes & $\%$ \\
\hline Non-speakers & $5,6 \%$ & Europe & $67,6 \%$ \\
\hline Basic & $15,5 \%$ & South America & $48,8 \%$ \\
\hline Intermediate & $24,9 \%$ & Asia & $14,1 \%$ \\
\hline Advanced & $54 \%$ & North America & $12,2 \%$ \\
\hline Spanish & $\%$ & Africa & $8,5 \%$ \\
\hline \multirow{2}{*}{$\begin{array}{l}\text { Non-speakers } \\
\text { Basic }\end{array}$} & \multirow{2}{*}{$\begin{array}{l}28,6 \% \\
27,2 \%\end{array}$} & Oceania & $2,3 \%$ \\
\hline & & Speaks other languages? & $\%$ \\
\hline Intermediate & $26,8 \%$ & No & $77,5 \%$ \\
\hline Advanced & $17,4 \%$ & Yes & $22,5 \%$ \\
\hline
\end{tabular}

Source: Field research database.

Thus, having described the profile of the sampled Brazilian backpackers, the attention of the statistical analyzes is directed towards verifying the consistency of the items comprising the scales and the dimensionality of the data. As the results of these analyzes are essential for multiple regression, they will be presented in detail in the following section.

\section{Reliability of items and dimensionality of data}

The reliability test consisted of measuring the Cronbach's alpha of all constructs in the model, with the rigor of maintaining only values equal to or above 0.7 (Hair et al., 2009). At this stage, no construct presented alpha lesser than 0.7 . The factor analysis was then performed in order to verify the alignment of the dimensions and indicators proposed in the scales. Barlett's KMO and sphericity tests were used. Table 5 summarizes the indices obtained for the reliability 
Araujo, C. Y. R., Costa, M. F., \& Silva, T. P. G. (2021, set./dez.). Change-seeking behavior and selfidentity in the satisfaction of brazilian backpackers with international backpacking trips

of the items and the dimensionality of the data. The session continues after the table with the details of the tests.

Table 5.

Reliability of Items and Dimensionality of Data

\begin{tabular}{|c|c|c|c|c|c|c|c|c|}
\hline \multirow{2}{*}{ Variables } & \multirow{2}{*}{ Loadings } & \multirow{2}{*}{$H^{2}$} & \multirow[t]{2}{*}{ KMO } & \multicolumn{3}{|c|}{ Barlett } & \multirow{2}{*}{ Exp.V,* } & \multirow{2}{*}{ Cronbach } \\
\hline & & & & Df & Quil $^{2}$ & Sig & & \\
\hline SIB01 & 0,885 & 0,714 & \multirow{3}{*}{0,673} & \multirow{3}{*}{3} & \multirow{3}{*}{198,370} & \multirow{3}{*}{0,000} & \multirow{3}{*}{70,403} & \multirow{3}{*}{0,758} \\
\hline SIB02 & 0,845 & 0,783 & & & & & & \\
\hline SIB03 & 0,785 & 0,616 & & & & & & \\
\hline CSB01 & 0,734 & 0,539 & \multirow{7}{*}{0,886} & \multirow{7}{*}{21} & \multirow{7}{*}{675,289} & \multirow{7}{*}{0,000} & \multirow{7}{*}{57,626} & \multirow{7}{*}{0,858} \\
\hline CSB02 & 0,848 & 0,719 & & & & & & \\
\hline CSB03 & 0,719 & 0,517 & & & & & & \\
\hline CSB04 & 0,828 & 0,674 & & & & & & \\
\hline CSB05 & 0,753 & 0,685 & & & & & & \\
\hline CSB06 & 0,576 & 0,567 & & & & & & \\
\hline CSB07 & 0,734 & 0,332 & & & & & & \\
\hline LSI01 & 0,734 & 0,539 & \multirow{3}{*}{0,627} & \multirow{3}{*}{3} & \multirow{3}{*}{123,990} & \multirow{3}{*}{0,000} & \multirow{3}{*}{62,806} & \multirow{3}{*}{0,703} \\
\hline LSI02 & 0,859 & 0,738 & & & & & & \\
\hline LSI03 & 0,779 & 0,608 & & & & & & \\
\hline GSI01 & 0,684 & 0,708 & \multirow{5}{*}{0,736} & \multirow{5}{*}{10} & \multirow{5}{*}{247,532} & \multirow{5}{*}{0,000} & \multirow{5}{*}{49,778} & \multirow{5}{*}{0,742} \\
\hline GSI02 & 0,689 & 0,710 & & & & & & \\
\hline GSI03 & 0,763 & 0,616 & & & & & & \\
\hline GSI04 & 0,806 & 0,683 & & & & & & \\
\hline GSI05 & 0,562 & 0,776 & & & & & & \\
\hline
\end{tabular}

All constructs were measured using single-dimension scales. The Satisfaction with Backpack (SIB) construct obtained reliability in Cronbach's alpha, remaining with its three original items. Adequacy KMO of 0.673 and sphericity with 3 degrees of freedom, chi-square of 198.370 and 0.000 of significance. All items loaded in a single factor. The Search for Change (CSB) construct had the highest alpha in the model, with 0.858. All items remained and loaded in a single factor. The KMO suitability test resulted in a value of 0.886 . Barlett's sphericity tests resulted in 21 degrees of freedom, chi-square of 675.289 and significance of 0.000 .

The scale of the construct of Local Self-identity (LSI) was the only one that needed corrections to reach an adequate level of dimensionality. Its initial reliability was 0.721 alpha, but due to low commonality, three items (LSI04, LSI05, LSI10) were removed. In order to comply with the single-factor running accuracy, the scale was finally reduced to three items (LSI01, LSI02, LSI03) with the following final values for the construct: 0.703 Cronbach's 
Araujo, C. Y. R., Costa, M. F., \& Silva, T. P. G. (2021, set./dez.). Change-seeking behavior and selfidentity in the satisfaction of brazilian backpackers with international backpacking trips

alpha, 0.627 KMO, with 3 degrees of freedom, chi-square of 123.990 and significance of 0.000 . These remaining three items represent $62.8 \%$ of explained variance.

Finally, the Global Self-identity (GSI) construct resulted in a Cronbach's alpha of 0.742 , passing the reliability test. Its dimensions were aligned, presenting a KMO of 0.736. Barlett's sphericity tests resulted in 10 degrees of freedom, chi-square of 247.532 and significance of 0.000. All items loaded in a single factor and none were removed.

\section{Analysis of the proposed theoretical model}

After dealing with the parameters of reliability and dimensionality, the items of each construct were grouped into composite variables (summated scale) to perform the regression. As shown in Table 6, the highest average of responses was in the Satisfaction with backpacking construct (SIB), with local self-identity (LSI) being the respondent's least agreeing construct.

\section{Table 6.}

Descriptive Statistics of the Composite Variables

\begin{tabular}{lllll|}
\hline Variables & $\mathrm{N}$ & Mean & S.D.* \\
\hline Satisfaction with international & 213 & 6,67 & 0,635 \\
backpacking trip & 213 & 5,65 & 1,044 \\
Change-seeking behavior & 213 & 4,71 & 1,293 \\
Local self-identity & 213 & 4,96 & 1,186 \\
Global self-identity &
\end{tabular}

Source: Field research database.

The multiple regression backward method was used, which resulted in the removal of the local self-identity (LSI) variable in model 2 , considering $p>=0.100$. It is demonstrated, therefore, that local self-identity (LSI) does not have a significant influence on the proposed theoretical model. Thus, $\mathrm{H} 2$ is rejected.

\section{Table 7.}

\section{Multiple Regression (backward method)}

\begin{tabular}{llll}
\hline Model & Variable entered & Variable removed & Method \\
\hline 1 & $\begin{array}{l}\text { global self-identity (GSI), local self-identity (LSI), } \\
\text { Change-seeking behavior (CSB) }\end{array}$ & Enter \\
2 & local self-identity (LSI) & $\begin{array}{l}\text { Backward (criterion: } \\
\text { Probability of F-to- } \\
\text { remove }>=, 100) .\end{array}$ \\
\hline
\end{tabular}

Source: Field research database. 
Table 8 summarizes the theoretical model. The $\mathrm{R}$ value corresponds to 0.292 , indicating a correlation between the independent variables and the SIB variable. The independent variables explain $8.5 \%$ of the Brazilian backpacker's satisfaction, a value measured from R2. In this study, the adjusted R2 value was $7.7 \%$, with a standard error of 0.610 .

Table 8.

Model Summary

\begin{tabular}{cccccc}
\hline Model & $\mathbf{R}$ & $\mathbf{R}^{2}$ & $\begin{array}{c}\text { Adjusted } \\
\mathbf{R}^{\mathbf{2}}\end{array}$ & S.E. & Durbin-Watson \\
\hline 1 & 0,304 & 0,092 & 0,079 & 0,610 & \\
2 & 0,292 & 0,085 & 0,077 & 0,610 & 1,737 \\
\hline
\end{tabular}

Source: Field research database.

The following table (Table 9) details the values obtained by ANOVA. Based on the results presented, it was found that the proposed theoretical model has statistical significance, albeit low. Thus, at least one of the independent variables is significant in explaining Brazilian backpacker's satisfaction with international trip. The F statistic resulted in a value of 9.789, also significant, suggesting that the simultaneous test that each coefficient is 0 (zero) was rejected.

Table 9.

Anova

\begin{tabular}{llccccc}
\hline Model & $\begin{array}{c}\text { Sum of } \\
\text { squares }\end{array}$ & df & Mean square & F & Sig. \\
\hline \multirow{2}{*}{$\begin{array}{l}\text { Regression } \\
\text { 1 Residual }\end{array}$} & 7,885 & 3 & 2,628 & 7,073 & 0,000 \\
& 77,662 & 209 & 0,372 & & \\
& Total & 85,547 & 212 & & & \\
\hline \multirow{2}{*}{2 Regression } & 7,295 & 2 & 3,648 & 9,789 & 0,000 \\
Residual & 78,252 & 210 & 0,373 & & \\
& Total & 85,547 & 212 & & & \\
\hline
\end{tabular}

Source: Field research database.

Table 10 shows the coefficients of the multiple regression analysis. The local selfidentity variable (LSI) is not present because it was discarded in the Backward method. The variables CSB and GSI scored within the established parameters, proving their influence on the satisfaction of the Brazilian backpacker with international trip. According to Beta values, the variables CSB and GSI corroborate the positive valence proposed by hypotheses $\mathrm{H} 1$ and $\mathrm{H} 3$, confirming them. 
Araujo, C. Y. R., Costa, M. F., \& Silva, T. P. G. (2021, set./dez.). Change-seeking behavior and selfidentity in the satisfaction of brazilian backpackers with international backpacking trips

Table 10.

Coefficients

\begin{tabular}{|c|c|c|c|c|c|c|c|c|}
\hline \multirow{2}{*}{\multicolumn{2}{|c|}{ Model }} & \multicolumn{2}{|c|}{$\begin{array}{c}\text { Unstandardized } \\
\text { coefficients }\end{array}$} & \multirow{2}{*}{$\begin{array}{c}\begin{array}{c}\text { Standardized } \\
\text { coeficiente }\end{array} \\
\text { B }\end{array}$} & \multirow{2}{*}{$\mathbf{t}$} & \multirow{2}{*}{ Sig. } & \multicolumn{2}{|c|}{$\begin{array}{l}95,0 \% \text { confidence } \\
\text { interval for B }\end{array}$} \\
\hline & & B & Std. Error & & & & $\begin{array}{l}\text { Lower } \\
\text { bound }\end{array}$ & $\begin{array}{l}\text { Upper } \\
\text { bound }\end{array}$ \\
\hline \multirow{4}{*}{1} & (Constant) & 5,472 & 0,286 & & 19,158 & 0,000 & 4,909 & 6,035 \\
\hline & CSB & 0,084 & 0,043 & 0,138 & 1,965 & 0,051 & 0,000 & 0,169 \\
\hline & LSI & 0,042 & 0,033 & 0,086 & 1,260 & 0,209 &,- 024 & 0,108 \\
\hline & GSI & 0,106 & 0,039 & 0,198 & 2,739 & 0,007 & 0,030 & 0,183 \\
\hline \multirow{3}{*}{2} & (Constant) & 5,638 & 0,254 & & 22,240 & 0,000 & 5,139 & 6,138 \\
\hline & CSB & 0,079 & 0,043 & 0,130 & 1,848 & 0,066 &,- 005 & 0,163 \\
\hline & GSI & 0,119 & 0,038 & 0,222 & 3,163 & 0,002 & 0,045 & 0,193 \\
\hline
\end{tabular}

Source: Field research database.

Confirmation of $\mathrm{H} 1$ was found, given its positive influence on the satisfaction of the Brazilian backpacker. Global self-identity has already been shown to be able to lead participants to prefer more globalized products over local products (Batra et al., 2000). With this study, it is proposed that the global self-identity is also present in the satisfaction of Brazilian backpackers with the backpacking trip as one of its influencing factors.

The result corroborates with the current discussions on the development of globalized identities in independent travelers and shows that a backpacker's globalized self-identity can positively affect travel satisfaction. In addition, the result is significant as recent research connects globalized identities to emerging and important themes such as a tendency to take collective and global action against global warming (Barth et al, 2015) and support for environmental movements (Rosenmann, Reese, \& Cameron, 2016). Studies have also shown that individuals take into account global brands and developed countries place-image to develop their own cosmopolitan identities (Srivastava \& Balaji, 2018).

The result of this study suggests that Brazilian backpackers are individuals who strongly identify with the world and this suggests an openness to products, brands and international experiences; strong concern with environmental issues worldwide and strong proximity to developed markets.

The rejection of $\mathrm{H} 2$ came from the removal of the LSI construct from the theoretical model due to its low level of significance. The construct concerns self-identification with the community in which one lives, their customs and traditions passed on by different generations in the same territory. In addition, it also deals with awareness of local events and consumption of local products. 
Araujo, C. Y. R., Costa, M. F., \& Silva, T. P. G. (2021, set./dez.). Change-seeking behavior and selfidentity in the satisfaction of brazilian backpackers with international backpacking trips

The low level of significance of the LSI may be an indication of the stronger-weaker relationship reported by Strizhakova and Coulter (2019) where certain individuals who have a strong global identity may present a lower local identity and vice versa. The result presented here suggests that the Brazilian backpacker can fit into the stronger global category (local weaker). It means that the global-local tug-of-war mentioned previously seems to be leaning towards a stronger sense of global self. However, it was not possible to say whether the local self-identity influences the satisfaction generated by backpacking. A possible explanation can be brought up by Zhang et al (2018) who claim that the change in political and social environments in western societies has meant that contemporary backpackers are less alienated from their place of origin than before.

Confirmation of H3 was found given the positive influence of the change-seeking behavior in the dependent variable. The construct indicates the characteristic of interest in the different and the break from routine. The result corroborates to a certain extent with that predicted by the literature, where backpackers are seen as searchers for novelties and changes not only in their routine, but in life changes as a whole (Noy, 2004).

The change-seeking behavior confirmed by this research as a factor of positive influence on the satisfaction with international backpacking trip suggests that the Brazilian backpacker is an individual who perceives change as stimulating and desirable, but only to some extent, considering the resulting significance index.

This result corroborates Cohen's (2011) statements that the backpacker as a type of tourist is increasingly approaching the traditional mass tourist in terms of receptivity to the unforeseen and unplanned. In the particular case of the Brazilian backpacker, it is possible that the influence of the change-seeking is reduced in the total explanation of satisfaction due to the high financial cost of a long trip abroad. This can make Brazilians more resistant to the search for change or that change can be seen as desirable, but risky; this would explain the reduced positive influence of the change-seeking behavior in the proposed theoretical model.

\section{Conclusion}

This study aimed to investigate the influence of global, local self-identity and the change-seeking behavior in the satisfaction of Brazilian backpackers traveling abroad. This research suggests that the Brazilian backpacker traveling abroad is above the national average in terms of income and foreign language proficiency. Another finding that may be of interest is 
Araujo, C. Y. R., Costa, M. F., \& Silva, T. P. G. (2021, set./dez.). Change-seeking behavior and selfidentity in the satisfaction of brazilian backpackers with international backpacking trips

that backpackers have chosen, in third place, Asia more than North America as a backpacking destination. One possible explanation is the greater proximity between Europe and Asia in the face of the continental isolation of North America. Eurasia seems to appeal more to the changeseeking behavior identified in the Brazilian backpacker given the cultural and geographical variety of the supercontinent. Thus, there seems to be a great untapped potential for Asian tourism in the Brazilian backpacking market.

This research also shed some light on the influencing factors in the satisfaction of this complex public, the backpacker. An important conclusion here it that consumers in a globalized world may develop two integrated identities to cope with global and local markets and these identities will influence the way they perceive, acquire and support products. Both identities push and pull costumer's consumption behavior with different strengths, something like a tugof-war. Understanding these emerging self-identities is particularly important for international tourism studies because they will influence part of the consumer travel decisions and consequently future travel satisfaction.

Recent research shows that backpackers with high global self-identity have characteristics such as valuing the global collective and the environment, products and globalized places. Therefore, the backpacker's global identity as an influencing factor in the satisfaction of his trip was confirmed as an important explanation for the discovery of the identity of this type of traveler. From the point of view of tourism marketing, it can be assumed that the Brazilian backpacker will be attracted by campaigns that connect his constant search for change with collective actions and in favor of the environment, as long as it is a relatively safe experience.

Although there is a relationship between these travelers and their local reality, there is a predominance of the search for the meaning of life through the practice of backpacking. In view of this statement, the result of this research is ratified because with the confirmation of the global identity, the local one is not relevant to explain the satisfaction of backpackers, since there is a predominance of the search for distance from their routine, work and issues associated their place of origin.

Regarding the search for change construct, the results presented of this study suggest that the changes, break of routine and adventures on the trip positively influence how satisfied a backpacker will be at the end of their trip. It can be concluded with this research that the Brazilian backpacker is a traveler with behaviors of search for change ratifying the literature when he affirms the most experienced western backpackers have a change of worldview 
Araujo, C. Y. R., Costa, M. F., \& Silva, T. P. G. (2021, set./dez.). Change-seeking behavior and selfidentity in the satisfaction of brazilian backpackers with international backpacking trips

through the backpacking trip. In this way, it contributes to reinforcing the characteristics of western backpackers presented in researches that search for novelties, are encouraged to discover new places and cultures and seek personal development and changes in the worldview.

Adding the characteristics revealed by this study, it can be said that the Brazilian backpacker who travels abroad is a consumer who identifies themselves with the globalized world, is motivated by the search for changes and presents themselves as a promising market niche since it is above the national average in educational, linguistic and financial levels. In addition, it fills a gap in investigations into the identity and behavior of western backpackers, a topic that has been poorly studied within this segment.

\section{Limitations and suggestions for future research}

This research has some limitations. The first one concerns the form of sampling selection, carried out by convenience. This fact prevents the findings from being able to be generalized to the entire population. In addition, the proposed theoretical model still explains little of the influencing factors in the satisfaction of the Brazilian backpacker, which makes this a pioneer yet still very exploratory study.

Therefore, it is proposed new research with a larger sample and to investigate new constructs that can be incorporated into the theoretical model proposed here. Possible constructs for investigation are Backpacker Personal Development and information sharing on a social network. The field is still recent and lacks empirical data.

COVID-19 pandemic and its relation to a possible weakening of the globalization process also presents an interesting topic for investigation. The future developments of backpacking tourism is strongly linked to the future of low-cost travel and stable geopolitical dynamics, both of which are currently endangered.

\section{Declaration of interest statement}

The authors declare that there is no conflict of interest.

\section{Acknowledgment}

The authors would like to thank the financial support from CAPES - Brazilian Federal Agency for Support and Evaluation of Graduate Education 
Araujo, C. Y. R., Costa, M. F., \& Silva, T. P. G. (2021, set./dez.). Change-seeking behavior and selfidentity in the satisfaction of brazilian backpackers with international backpacking trips

\section{References}

Alves, S., Abrantes, J. L., Antunes, M. J., Seabra, C., \& Herstein, R. (2016). WOM antecedents in backpacker travelers. Journal of Business Research, 69(5), 1851-1856. https://doi.org/10.1016/j.jbusres.2015.10.068

Arnett, J. J. (2002). The Psychology of Globalization. American Psychological Association, 57(10), 774-783. https://doi.org/10.1037/0003-066X.57.10.774

Barth, M., Jugert, P., Wutzler, M., \& Fritsche, I. (2015). Absolute moral standards and global identity as independent predictors of collective action against global injustice. European Journal of Social Psychology, 45(7), 918-930. https://doi.org/10.1002/ejsp.2160

Batista, K. T., Andrade, R. R., \& Bezerra, N. L. (2013). O papel dos comitês de ética em pesquisa. Rev Bras Cir Plást., 27(1), 150-155. https://doi.org/10.1590/S198351752012000100025

Baumgartner, H., \& Steenkamp, J. B. (2001). Response Styles in Marketing Research: A Cross-National Investigation. Journal of Marketing Research, 38, 143-156. https://doi.org/10.1509/jmkr.38.2.143.18840

Bello, D.; Etzel, M. (1985). The role of novelty in the pleasure travel experience. Journal of Travel Research, 20-26. https://doi.org/10.1177/004728758502400104

Barbosa, A., O’Neill, B., Ponte, C., Simões, J.A., \& Jereissati, T. (2013). Risks and safety on the internet: Comparing Brazilian and European children. LSE, London: EU Kids Online. https://doi.org/10.21427/D7V02Q

Burity, J. A. (2008). Brazil's rise: Inequality, culture and globalization. Futures, 40(8), 735747. https://doi.org/10.1016/j.futures.2008.02.001

Cai, W., Cohen, S. A., \& Tribe, J. (2019). Harmony rules in Chinese backpacker groups. Annals of Tourism Research, 75, 120-130. https://doi.org/10.1016/j.annals.2018.12.010

Chen, Ganghua; Bao, Jigang; Huang, Songshan. (2014). Developing a Scale to Measure Backpackers' Personal Development. Journal of Travel Research, 53(4), 522-36. https://doi.org/10.1177/0047287513500392

Chen, G. H., \& Huang, S. (Sam). (2019). Backpacker tourism: a perspective article. Tourism Review, 75(1), 158-161. https://doi.org/10.1108/TR-06-2019-0271

Chen, G., Huang, S. (Sam), \& Hu, X. (2019). Backpacker Personal Development, Generalized Self-Efficacy, and Self-Esteem: Testing a Structural Model. Journal of Travel Research, 58(4), 680-694. https://doi.org/10.1177/0047287518768457.

Chen, G., \& Huang, S. S. (2017). Toward a theory of backpacker personal development: Cross-cultural validation of the BPD scale. Tourism Management, 59, 630-639. 
Araujo, C. Y. R., Costa, M. F., \& Silva, T. P. G. (2021, set./dez.). Change-seeking behavior and selfidentity in the satisfaction of brazilian backpackers with international backpacking trips

https://doi.org/10.1016/j.tourman.2016.09.017.

Chen, G. Zhao, L., \& Huang, S. (2020). Backpacker Identity: Scale Development and Validation. Journal of Travel Research, 59(2), 281-294. https://doi.org/10.1177/0047287519829255

Cohen, E. (2003). Backpacking: Diversity and change. Journal of Tourism and Cultural Change, 1(2), 95-110. https://doi.org/10.1080/14766820308668162

Cohen, S. (2011). Lifestyle travellers. Annals of Tourism Research, 38(4), 1535-1555. https://doi.org/10.1016/j.annals.2011.02.002

Cohen, Scott A. (2010). Personal Identity (De)formation among Lifestyle Travellers: A Double-Edged Sword. Leisure Studies, 29(3), 289-301.

https://doi.org/10.1080/02614360903434100

Collins-Kreiner, N., Yonay, Y., \& Even, M. (2018). Backpacking memories: A retrospective approach to the narratives of young backpackers. Tourism Recreation Research, 43(3), 409-412. https://doi.org/10.1080/02508281.2018.1464637

Costa, M. F., Paula, T. S., Angelo, C. F., \& Fouto, N. M. M. D. (2017). Personalidade da marca, significado do produto e impulsividade na compra por impulso: um estudo em ambiente de shopping center. RECADM: Revista Eletrônica de Ciência Administrativa, 16, 151-166. https://doi.org/10.21529/RECADM.2017007

Creswell, J. W. (2010). Projeto de pesquisa: métodos qualitativo, quantitativo e misto (3a edição). Porto Alegre: Artmed.

Dabholkar, P., \& Bagozzi, R. (2002). An Attitudinal Model of Technology Based SelfService: Moderating Effects of Consumer Traits and Situational Factors. JAMS, 30(3), 184-201. https://doi.org/10.1177/0092070302303001

Dayour, F., A. N. Kimbu, and S. Park. (2017). Backpackers: The Need for Reconceptualization. Annals of Tourism Research, 66, 191-193. https://doi.org/10.1016/j.annals.2017.06.004

Dayour, F., Park, S., \& Kimbu, A. N. (2019). Backpackers' perceived risks towards smartphone usage and risk reduction strategies: A mixed methods study. Tourism Management, 72, 52-68. https://doi.org/10.1016/j.tourman.2018.11.003

Edensor, T. (2001). Performing tourism, staging tourism: (Re)producing tourist space and practice. Tourist Studies, 1(1), 59-81. https://doi.org/10.1177/146879760100100104

Falconer, E. (2013). Transformations of the backpacking food tourist: Emotions and conflicts. Tourist Studies, 13(1), 21-35. https://doi.org/10.1177/1468797613477769

Garlington, W. K.; Shimota, H. E (1964). The change seeker index: A measure of the need for variable stimulus input. Psychological Reports, 14, 919-924.

https://doi.org/10.2466/pr0.1964.14.3.919 
Araujo, C. Y. R., Costa, M. F., \& Silva, T. P. G. (2021, set./dez.). Change-seeking behavior and selfidentity in the satisfaction of brazilian backpackers with international backpacking trips

Hermans, H. J. M. \& Dimaggio, G. (2007). Self, identity, and globalization in times of uncertainty: a dialogical analysis. Review of General Psychology, 11(1), 31-61. https://doi.org/10.1037/1089-2680.11.1.31

Loker, L. (1991). The backpacker phenomenon II: More answers to further questions. Townsville: Department of Tourism, James Cook University.

Makri, K., Papadas, K.-K. and Schlegelmilch, B. B. (2019).Global-local consumer identities as drivers of global digital brand usage. International Marketing Review, 36(5), $702-$ 725. https://doi.org/10.1108/IMR-03-2018-0104

Malhotra, N. K. (2012). Pesquisa de Marketing: uma orientação aplicada (6th ed.). Porto Alegre: Bookman.

Nakamura, K. (2015). Problema do caixeiro viajante mochileiro: formulações e métodos de soluções. 2015. Dissertation (Masters) - Instituto de Ciência e Tecnologia, Universidade Federal de São Paulo (UNIFESP), São José dos Campos, Brazil. http://repositorio.unifesp.br/handle/11600/46303

Noy, C. (2004). This trip really changed me: Backpackers' narratives of self-change. Annals of Tourism Research, 31(1), 78-102. https://doi.org/10.1016/j.annals.2003.08.004

O'Reilly, C. (2006). From drifter to gap year tourist - mainstreaming back-packer travel. Annals of Tourism Research, 33, 998-1017. https://doi.org/10.1016/j.annals.2006.04.002

Paris, C. M. (2012). Flashpackers: An emerging sub-culture? Annals of Tourism Research, 39(2), 1094-1115. https://doi.org/10.1016/j.annals.2011.12.001

Pearce, P. L. (1990). The backpacker phenomenon: Preliminary answers to basic questions. Townsville: James Cook University of North Queensland.

Rosenmann, A., Reese, G., \& Cameron, J. E. (2016). Social identities in a globalized world: Challenges and opportunities for collective action. Perspectives on Psychological Science, 11, 202-221. https://doi.org/10.1177/1745691615621272

Steenkamp, Jan-Benedict E. M. \& Baumgartner, H. (1995). Development and Cross Cultural Validation of a Short form of CSI as a Measure of Optimum Stimulation Level. International Journal of Research in Marketing, 12(2), 97-104. https://doi.org/10.1016/0167-8116(93)E0035-8

Srivastava, A. \& Balaji, M. S. (2018). Consumer dispositions toward global brands. Marketing Intelligence \& Planning, 36(6), 618-632. https://doi.org/10.1108/MIP-112017-0290

Tu, L., Khare, A. \& Zhang, Y. (2012). A short 8-item scale for measuring consumers' localglobal identity. International Journal of Research in Marketing, 29(1), 35-42. https://doi.org/10.1016/j.ijresmar.2011.07.003 
Araujo, C. Y. R., Costa, M. F., \& Silva, T. P. G. (2021, set./dez.). Change-seeking behavior and selfidentity in the satisfaction of brazilian backpackers with international backpacking trips

Wang, J., Huang, X., Gong, Z., \& Cao, K. (2020). Dynamic assessment of tourism carrying capacity and its impacts on tourism economic growth in urban tourism destinations in China. Journal of Destination Marketing \& Management, 15, 100383. https://doi.org/10.1016/j.jdmm.2019.100383

Westjohn, A., Arnold, M., Magnusson, P., Zdravkovic, S. \& Zhou, J. (2009). Technology Readiness and Usage: A Global-Identity Perspective. Journal of the Academy of Marketing Science, 37(3), 250-265. https://doi.org/10.1007/s11747-008-0130-0

Uriely, N., Yonay, Y., \& Simchai, D. (2002). Backpacking experiences: A type and form analysis. Annals of Tourism Research, 29(2), 520-538. https://doi.org/10.1016/S01607383(01)00075-5

Zahra, A., \& Mcintosh, A. J. (2007). Volunteer tourism: Evidence of cathartic tourist experiences. Tourism Recreation Research, 32, 115-119. https://doi.org/10.1080/02508281.2007.11081530

Zhang, Y., \& Khare, A. (2008). Consumers' Local-Global Identity: Measurement, in Advances in Consumer Research, v. 36, eds.. Ann L. McGill and Sharon Shavitt, Duluth, MN: Association for Consumer Research, 41-44.

Zhang, Y., \& Khare, A. (2009). The Impact of Accessible Identities on the Evaluation of Global versus Local Products. Journal of Consumer Research, 36(3), 524-537. https://doi.org/10.1086/598794

Zhang, J., Morrison, A. M., Tucker, H., \& Wu, B. (2018). Am I a Backpacker? Factors Indicating the Social Identity of Chinese Backpackers. Journal of Travel Research, 57(4), 525-539. https://doi.org/10.1177/0047287517702744

Zhang, J., Tucker, H., Morrison, A. M., \& Wu, B. (2017). Becoming a backpacker in China: A grounded theory approach to identity construction of backpackers. Annals of Tourism Research, 64, 114-125. https://doi.org/10.1016/j.annals.2017.03.004 